\title{
Occupational Exposure to the Nitrogen Based Fertilizer: A Severe Case of Irritant Contact Dermatitis
}

\author{
Nitrojen Bazıı Gübreye Mesleki Maruziyet: Ağır Bir Irritant Kontakt Dermatit Olgusu
}

\author{
Ömer Faruk Elmas', Okan Kızılyel', Mahmut Sami Metin², Handan Bilen', Mustafa Atasoy' \\ ${ }^{1}$ Atatürk University, Faculty of Medicine, Dermatology Department, Erzurum; ${ }^{2}$ Afşin State Hospital, Dermatology Clinic, Kahramanmaraş
}

\begin{abstract}
Nitrogen is a chemical substance used in cryobiology, cryotherapy and agriculture. Here, we have reported a case of 19-years-old male farmer that developed severe bullous lesions on both of his legs after occupational exposure of nitrogen based liquid fertilizer through the strawberry leaves. Fertilizer induced contact dermatitis has extremely rare been reported in the literature. We have highlighted the importance of protection from occupational exposure to the fertilizers in this case.
\end{abstract}

Key words: contact dermatitis; nitrogen fertilizer; strawberry leaves

\section{ÖZET}

Nitrojen kriyobiyoloji, kriyoterapi ve tarımda kullanılan kimyasal bir maddedir. Burada, çilek yapraklarına kullanılan nitrojen bazIı gübreye maruz kalınması sonrası her iki bacağında ciddi büllöz lezyonları gelișen, 19 yașında erkek çiftçi olgusunu sunduk. Literatürde gübrenin tetiklediği kontakt dermatitler çok nadirdir. $\mathrm{Bu}$ olguda mesleki gübreye temasın önlenmesinin önemini vurgulamak istedik.

Anahtar kelimeler: kontakt dermatit; nitrojen gübre; çilek yaprakları

\section{Introduction}

Nitrogen is a chemical substance that used in cryobiology and cryotherapy, especially in dermatology. It is also an essential element required for successful plant growth that the most used variety of fertilizer in agriculture ${ }^{1}$. Direct skin contact with liquid nitrogen causes severe skin irritation called cryogenic burns.

Asistan Okan Kizılyel, Atatürk Üniversitesi Dermatoloji Kliniğgi 5. Kat Erzurum Merkez 25000 Erzurum - Türkiye, Tel. 05542304603

Email.erester34@hotmail.com

Gelis Taribi: 08.11.2014 • Kabul Tarihi: 09.03.2015

\section{Case History}

A 19-years-old strawberry picker man was admitted to our clinic with severe vesicular and bullous lesions accompanied with complaints of intensely itching and burning. Lesions were on erythematous base and localized on his both legs (Fig. 1). He had worked in strawberry field approximately 12 hours before onset of lesions. The lesions were limited to uncovered contact area with the leaves. He had applied a nitrogen based liquid fertilizer to the strawberry leaves and shortly after had begun to work in the field. He had a continuously contact with the leaves while he was working. Patient has no history of any allergy, medication or disease include contact or food allergy to the strawberry and strawberry leaves. Patch test was not performed because patient denied. Laboratory investigations were completely with in normal limits. No any microorganism detected in cultures obtained from blisters fluid. Histological examination of biopsy specimen showed lack of epidermis and mixed inflammatory infiltrate of lymphocytes in superficial dermis (Fig. 2). Direct immunofluorescence staining was negative. Based on these findings, we made a diagnosis of irritant contact dermatitis due to nitrogen based fertilizer. Patient treated with a short tapering course of systemic methylprednisolone $(40 \mathrm{mg} /$ day, tapered by $5 \mathrm{mg} /$ day), topical wed dressing and topical antibiotic. The lesions resolved completely in 25 days without any complication.

\section{Discussion}

Farmers are exposed to many skin damaging factors. In a study that include 132 farmers of diagnosed with contact dermatitis, causes of 13 percent were found to be chemical irritants such as fertilizers, pesticides etc. 


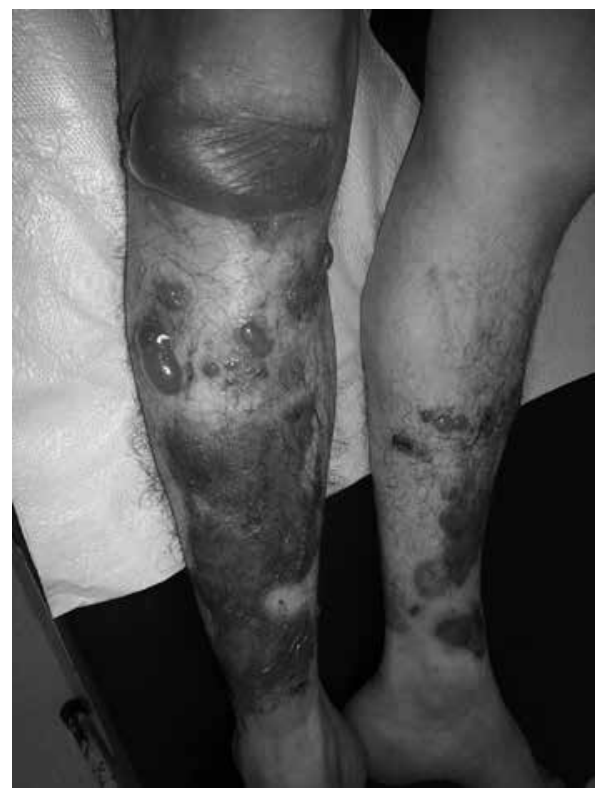

Figure 1. Lesions on erythematous base and localized on his both legs.

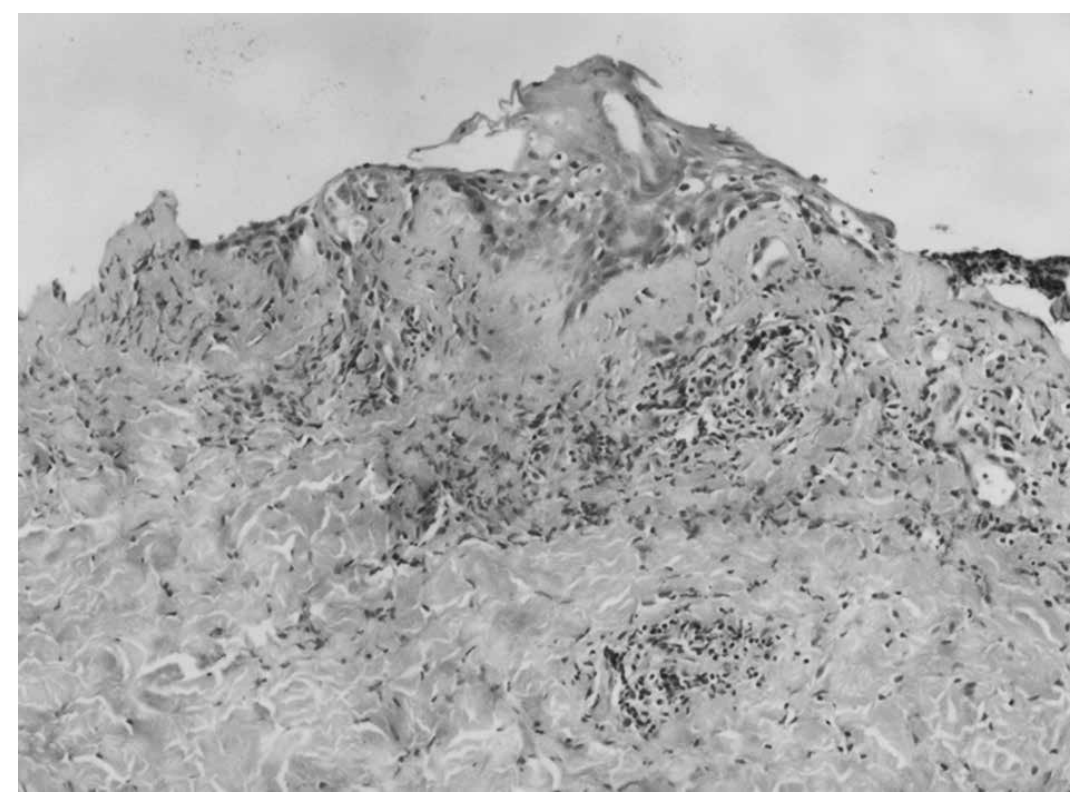

Figure 2. Histological examination of biopsy specimen showed lack of epidermis and mixed inflammatory infiltrate of lymphocytes in superficial dermis.
These chemical irritants cause an extent and severe dermatitis according to the other contact factors ${ }^{2}$. Despite the widespread use, there are a few reports about contact injuries caused by nitrogen ${ }^{3,4}$. Moreover, fertilizer induced contact dermatitis has extremely rare been reported in the literature ${ }^{5,6}$. Foti et al. reported a case of allergic contact dermatitis due to a fertilizer containing cyanamid that can transform ammonium carbonate, a source of nitrogen ${ }^{5}$. In the case, patient presented with severe and itchy vesicular and bullous lesions like our case.

\section{Conclusion}

We would like to emphasize that the nitrogen based fertilizers exposure causes more severe and wider skin reaction than other variety of fertilizers. For this reason, protection from contact exposure to the fertilizers, especially from nitrogen fertilizers is very important issue of occupational safety and health in agriculture.

\section{References}

1. Liu CW, Sung Y, Chen BC, Lai HY. Effects of nitrogen fertilizers on the growth and nitrate content of lettuce (Lactuca sativa L.). Int J Environ Res Public Health 2014:22;11(4):4427-40.

2. Kieć-Swierczyńska M1, Krecisz B, Swierczyńska-Machura D. Most frequent causes of allergic contact dermatitis in farmers: based on material collected in the Nofer Institute of Occupational Medicine, Lodz. Med Pr 2003;54(3):237-43.

3. Kandamany N, Ahmad M. Cool it!!--the judicious use of liquid nitrogen for viral warts is important. J Plast Reconstr Aesthet Surg 2010;63(2): e204.

4. Kernbach-Wighton G1, Kijewski H, Schwanke P, Saur P, Sprung R. Clinical and morphological aspects of death due to liquid nitrogen. Int J Legal Med 1998;111(4):191-5.

5. Foti C, Bonamonte D, Conserva A, Pepe ML, Soleo L, Angelini G. Allergic contact dermatitis with a fertilizer containing hydrogen cyanamide (Dormex). Cutan Ocul Toxicol 2008;27(1):1-3.

6. Lazarov A, Yair M, Lael E, Baitelman L. Airborne irritant contact dermatitis from phosphates in a fertilizer factory. Contact Dermatitis 2002;46(1):53-4. 